\title{
A manifesto for critical narrative research and pedagogy for/with young children: Teacher and child as critical annalist
}

\section{Michael O'Loughlin}

Abstract: In this essay I pose the question of whether it might be possible to articulate a collaborative, critical narrative mode of research in which teachers and students come together using a critical and analytic epistemology to engage in adventurous pedagogy. This approach has echoes of Freire's "teachers-as-students and students-as-teachers," but elaborates the Freirean metaphor to include conceptions of emotion, creativity, and incorporation of the latent historical subjectivities of teachers and students in the process. Contrary to the deadening, circumscribed epistemology of putatively "evidence-based" pedagogies, in which teachers and children are expected to check their cultural meaning-making capacities and their emotional investments at the door, this is a plea for a regenerative, engaged, local curriculum making process. As I note in the essay, "This is a strategy that cannot work in the service of utilitarian modes of education that are focused only on value (cf. Appiah, 2015). It can only work for forms of schooling that seek to foster values of receptivity, cultural respect, open-mindedness, and critical imaginaries. In these coldly utilitarian times we need to provide leadership to progressively minded teachers to allow them to develop, document, and disseminate such practices."

Keywords: collaborative inquiry, critical narrative research, critical inquiry, teacher as critical researcher, teacher as annalist.

Working across two disciplines has made me acutely aware of the hegemonic forces that are operating to instrumentalize human service professions; 
to objectify human beings and flatten difference; and to co-opt human service work in the interests of creating neoliberal subjectivities that are needed to sustain the kind of capitalist societies that are emerging early in the twenty first century. Service delivery in one of my fields, clinical psychology, for example, is intimately tied in with the development of corporate health services. The power of the pharmaceutical industry to dictate mental health policy and treatment protocols, and the continued refinement by psychologists of the Diagnostic and Statistical Manual (DSM-5: American Psychiatric Association, 2013) as a tool for categorizing human characteristics, serve to reduce complex human suffering to frequency counts of supposedly objective symptoms and disorders. This has helped to normalize psychic distress as disease, and medical treatment as cure. The rise of 'evidence-based' treatment protocols - to count it must be countable-the insistence on time-limited interventions, and the movement toward manualized therapies, where lesser qualified practitioners can administer therapy by following a script, are integral to a capitalist system that negates the complexity of human suffering and seeks short-term profit through hegemonic and normalizing definitions of health and treatment.

The tragedy is compounded in that in dealing with persons with chronic psychiatric suffering-many of whom have experienced or inherited psychological trauma-psychology seeks to deal with some of the most vulnerable and marginal people in our societies. The history of psychology and psychiatry has been defined by indifference to variation, and psychology has established hegemony by controlling the levers of normalization: assessment and treatment. The remarkable success of psychology and psychiatry as the go-to source for diagnosis and treatment is in no small part tied to delimiting and prescriptive systems of accreditation which, while ostensibly paying lipservice to variation through such tropes as 'diversity' and 'inclusion', serve to delimit human subjectivity in ways that have profound consequences for both the delivery of clinical services and the conceptualization of research in the field. With the increasing trend toward globalization of westernized psychic concepts, the notions of human subjectivity embodied in the DSM, and in other reductionist psychological constructs such as PostTraumatic Stress Disorder [PTSD] are gaining hegemony across the globe (Fassin \& Rechtman, 2009; O'Loughlin, 2012a, 2015a; Watters, 2010). In terms of research, positivist discourses have maintained a hegemonic grip on psychology and psychiatry, and work that seeks to advance narrative understandings of human experience, or work that poses critical questions about human subject formation is relegated to the margins (O'Loughlin \& Charles, 2012; O’Loughlin et al., 2014). 
The foregoing discourse will sound eerily familiar to readers knowledgeable about the pressures that educators are experiencing with the advent of putative 'evidence-based' neo-liberal 'reforms' in schooling over the course of the last thirty years. On the plus side, education has benefited from a long history of critical and social justice oriented inquiry into the nature and purposes of schooling, much of it anchored in the earlier work of Dewey (1938/1998) and Counts (1932/1969), and more recently in Freireanbased critical pedagogies (Giroux, 2011; Kincheloe, 2008; McLaren, 1989). A robust tradition of critical ethnographic and narrative inquiry has also emerged, building from a critique of master narratives, of power and of white privilege, to an exploration of the intersectionalities of race, class, and gender oppressions and the complexities of articulating an education mission wrapped around more inclusive and critical ideas such as youth studies, rather than univocal normative notions of childhood (Bloch, Swadener \& Cannella, 2012; Britzman, 1995; Fine, 1994; Ibrahim \& Steinberg, 2014). A body of work also argues for the reclamation of emotion as a legitimate field of inquiry and as a basis for understanding epistemophilic and imaginative growth in children (Boler, 1999; Field, Cohler, \& Wool, 1989; Greene, 1978, 2001; O'Loughlin, 2009, 2013a, 2013b).

Yet, for all the vibrancy of these academic traditions, such critical lines of inquiry appear to have had negligible impact on the practice of teaching and the conduct of schooling. For example, some thirty years ago, Henriques and colleagues presented a compelling critique of the problematic foundational assumptions of approaches to children and schooling that are based on a developmental psychology paradigm that is inherently teleological, normative, and exclusionary, and that produces an essentialized, uniform subjectivity (Henriques et al., 1984; O'Loughlin, 2009, 2012b). Regrettably, that work, and the lineage of critical inquiry that followed from it, appears to have had negligible influence on the constructions of childhood underlying schooling. To the extent that there is a metatheory underlying what we teach teachers about children, it is the notion of the normal or typical child. Those children who are class-, gender-, ethnicity-, or ability-variant are viewed as different-and all too often as deficient-and pedagogical strategies of 'inclusion' are then articulated to bring them closer to the supposed norm. In commenting on linear models of growth, Stockton noted that we expect all children to grow up. Why is there no room for the possibility of, for example, sideways growth (Stockton, 2009) or rhizomatic growth (O'Loughlin \& Van Zile, 2012)? This prescriptive and reductionist process negates discursive understandings of subjectivity and fails to acknowledge the location of children in discursive and ideological matrices. Neither is there a pedagogical 
intent to assist children in reading their discursive locations critically or in trying out subaltern identifications. To put it parsimoniously, schooling is principally about assimilation, and the more divergent a particular child is from the norm, the more urgent and intense the assimilative intent becomes. A clear example of this in the U.S. is the hegemonic system of accreditation imposed on teacher education schools. Supposed standards are articulated by professional education associations, which, in collusion with state regulators and commercial publishers, have developed putatively 'evidence-based' practices and reductionist norms for teacher competence in which childhood is assumed to evolve in a linear process, and in which learning is best considered as the acquisition of measurable bits of 'knowledge'. There is no interest in cultivating epistemophilic instincts in children, nor in understanding the relationship between a child's emotional state and that child's capacity to experience wonder or even to simply feel good. Just as curriculum and testing are imposed on teachers and children in schools, the rubrics embedded in, for example Danielson's widely used Frameworks for Teaching (Danielson, 2013) impose a straitjacket on novice teachers and prepare them all too well for schools in which they are expected to willfully occlude children's voices, emotions, and imaginations in order to cover the prescribed curriculum compliantly. A preschool director, interviewed by $\mathrm{Pa}-$ ley, expressed it this way:

I'm not inclined to encourage fantasy play any more if my teachers can't handle it... If the teachers are worried about what's coming out, especially with the fours and fives, everyone is better off if we stick to lesson plans and projects.

"Has the play changed that much?" I asked.

The teachers think so. Maybe it's the increased tension since 9/11. Children do seem less prepared, more at risk. We're on safer ground with a somewhat academic curriculum. It's more dependable. (2004, p. 7)

The lack of critical underpinnings in teacher preparation and the sanitary cordon imposed by 'evidence-based' ideologies, high-stakes testing, and 'common core' curricula have eroded a great deal of teacher autonomy (Biesta, 2007). This has created conditions that deny teachers the opportunity to critique the system or to speak truth to power. In the U.S., for example, the 'school choice' movement has led to the rapid growth of charter schools, which, though publicly funded through school vouchers, typically do not 
recognize teacher unions, do not pay competitive salaries and do not offer the security of tenure. The changing ideological landscape of schooling poses complex challenges for teaches and children and raises ethical question for researchers who must navigate a terrain where asking troubling questions may not be welcomed, and where collaboration with transgressive inquiry may prove dangerous for teachers who cannot count on protection from principles of academic freedom or from the rights negotiated by a collectively bargained teacher's union contract. How is it possible, then, to conceptualize a critical research agenda that has transgressive potential and that might create space for those teachers who toil on despite an awareness that much of what they are expected or even coerced to do lacks soul and is not in the interests of the children they teach?

\section{Doing Research that Matters with Teachers and Children}

While it is somewhat soothing to depict the neo-liberal system as the Other-the bogeyman - the truth is that those of us who draw salaries from institutional systems, publish our work through commercial publishers, obtain research grants, participate in policy formulation, travel using funds from our institutions, or conduct non-collaborative or objectifying research on teachers or children, are all participants in the hegemonic power structures that some of us simultaneously critique. Many of us work in institutions that have acceded to the yoke of accreditation. In both the psychology and education schools at my institution we are expected to modify our syllabi to conform to uniform standards. In Education we are expected to participate willingly in committees that delimit our work and deligitimate the social justice principles we believe in. All the while we are dragooned into crafting and publishing glossy institutional statements and aspirational logos that claim to value diversity, imagination etc. as educational goals, in order to appease the tyrannical accreditation hegemon which actually seeks to undermine these very aspirations. What hypocrisy we live! Yet the world is not binary. We diminish our capacity to exploit the dialecticism inherent in apparently totalizing systems if we reduce complex issues to simple us-or-them equations. Such thinking can render us powerless in the face of hegemonic systems, especially when our colleagues embrace them with a grimace or sometimes with frothy glee. From a perspective of revolutionary praxis Gramsci's (1971) notion of organic intellectual is fruitful in thinking about the struggle around schooling (cf., Borg, Buttigieg \& Mayo, 2002; Mayo, 2010). Could it be that in modeling social-justice oriented praxis in our pedagogy and in our intellectual work, and in seeking to practice as 
organic intellectuals, we can recruit fellow travelers from among teachers to create an alternative imaginary and a critical praxis? It is this utopian goal that I wish to explore in the remainder of this essay.

Before proceeding I will offer one qualification to the possibility of working in a critical praxis with teachers. In setting up the Citizenship Education Schools that served as a critical site for activist training and citizen participation in the U.S. Civil Rights Movement, Myles Horton (1990; Horton \& Freire, 1990) shunned conventionally trained teachers and instead chose beauty parlor owners as key literacy trainers. He sought people who had organic connections to their community; who were not vulnerable to manipulation by overlords who paid their salaries; and who had not been indoctrinated into the sterile and stultifying practices through which children are objectified, curriculum is prescribed rather than derived, and children are mere supplicants at the feet of authority. The delivery of 'training' to teachers is, at least as calcified now, more than fifty years later, and the space for revolutionary praxis may even have shrunken. The demand is for 'evidencebased practice' but the notion of evidence is severely reductionist. My sense is that the kind of collaborative research praxis that I propose will work best with educators who come together voluntarily-either in person or over virtual networks-united in a desire to follow their instincts and develop a soulful, imaginative critical praxis with children. I have limited faith that it is possible to develop such organic processes within the ossified hegemonic structures of accredited university or institutional training programs.

The world of psychoanalytic training may point to a different way forward. Psychoanalysis is a shrinking profession, and one beset with struggles for legitimacy and relevance in a changing world (Stepansky, 2009). Yet it is a community distinguished by the vitality and almost fanatical zeal of its adherents. Participants in psychoanalytic training have until recently managed to resist hegemonic accreditation processes and the kinds of limitations universities placed on typical credit-bearing programs. The core of analytic training is a journey into self through a lengthy personal analysis, accompanied by years of one-on-one clinical supervision. As Bion (1962/1984) so aptly stated, psychoanalysis is about learning from experience. Psychoanalysts have continued the tradition pioneered by Freud and his peers, of building theory empirically from individual clinical case studies, and Freud's own writings offer compelling examples of the power of narrative inquiry and the inexhaustible possibilities that accompany living a questioning life. The joyful, yet insistent pedagogy pioneered by Myles Horton and still practiced at Highlander Research and Education center (http://highlandercenter.org/) 
also offers a powerful testament to a pedagogy that can emerge when people form a community of learners. Paulo Freire summarized the kind of learning in question thus:

Through dialogue, the teacher-of-the-students and the students-ofthe-teacher cease to exist and a new term emerges: teacher-student with students-teachers. The teacher is no longer merely the-one-whoteaches, but one who is himself taught in dialogue with the students, who in turn while being taught also teach. They become jointly responsible for a process in which all grow. In this process, arguments based on "authority" are no longer valid; in order to function authority must be on the side of freedom, not against it. Here, no one teaches another, nor is anyone self-taught. People teach each other, mediated by the world, by the cognizable objects which in banking education are "owned" by the teacher. (1970, p. 27)

In what follows I will outline some of the core principles underlying such a learning partnership, a process that holds out hope for eliding the distinction between pedagogy and research, instead offering possibilities for a grounded form of inquiry in which documentation processes are integral to inquiry, and hence to a grounded form of 'research' co-constructed by teachers and students. The question in the subtext of my discussion is whether indeed we can create a movement of teachers interested in learning from experience and interested in engaging in similar processes of inquiry in the company of their students.

\section{A metaphor: Teacher as Analyst / Annalist}

Despite sustained argument by adult learning theorists (Brookfield, 2004; Daloz, 1986; 2012) that teachers as adult learners be offered expansive opportunities for personal growth and the development of critical awareness, teacher education continues to prepare teachers technocratically, leading Britzman (2003) to reach the depressing conclusion that our modes of teacher induction too often amount to a sterile practice makes practice. In order for teachers to lead their students in inquiry, it would seem necessary to create facilitative spaces in which teachers themselves can engage in sustained, critical inquiry about their own origins; about the sociopolitical constitutedness of schooling; about the fostering of imagination; about the emotional vulnerabilities of children; and about the fostering of community as a fundamental value, as opposed to the currently prevailing emphasis on compliance and control. Autobiographical work provides an essential 
starting point. Consider, for example, the ways in which a teacher's own past is likely to be highly influential in how encounters with children are managed. Many authors have commented, for example, on how processes of what psychoanalysts refer to as transference and countertransference play themselves out in the classroom (Cozarelli \& Silin, 1989; Jersild, 1955; Littner, 1989; Pianta, 1999). Others have noted that a teacher's own lifestage, and the kinds of emotional life commitments the teacher has at a particular phase of life are likely to exert a profound influence in how children are received or reacted to on a given day or in a given year (Basch, 1989; Ekstein, 1989; Pianta, 1999). As Ekstein noted, young teachers, because of their proximity to their own childhoods, are likely to teach for love in the form of approval, while mature teachers may graduate to teaching for love of learning (1989).

Discussion of transference introduces the concept of the unconscious, a subject that is conspicuous for its absence from educational discourses. In contemporary psychoanalytic discourse unconscious processes are understood to include a significant sociocultural component. Our subjectivity is assumed to include not only the intrapsychic processes we normally describe as emotions, but each person is assumed to have a latent historical subjectivity that includes ancestral and cultural memory (O'Loughlin, 2015; O'Loughlin \& Charles, 2015). These latent knowledges can only be accessed through the exhumation of ancestral and local narratives and epistemologies:

To the extent that teacher education programs have depth, it is invariably in the area of delivery of received curriculum, and the facilitation of cognitive outcomes. A focus on the unconscious requires a considerable reassessment of the goals and intent of teacher education. It is worth noting here that while there are profound intellectual components to an imaginative pedagogy of the kind I envisage the mundanely cognitive is not privileged. Instead, important weight is given to ancestral memory, current emotion, the cultural and historical context of children's lives, and the power of epistemologies and narrative modes that transcend delimited Western notions of logos, the kinds of reductionist learning that can be boiled down to answers on multiple choice tests. (O'Loughlin, 2009, p. 161)

The term 'latent historical subjectivities' refers to what Bollas (1989) describes as the unthought knowns-those aspects of our being that are implicit, and that can be examined, and worked with through processes of 
rendering them nameable and speakable. This process of naming can be done, of course, through the traditional talk therapy that is psychoanalysis, but also through a variety of oral and written narrative modes of expression, through artistic and performative modalities, and through exposure to myth, storytelling, ritual, film, and drama that can readily be embodied in performative pedagogical processes. Atkinson (2001), writing of her work with Indigenous Australians, suggest that lore is a vital component of human subjectivity, and that culturally alienated people experience a debilitating condition she refers to as lorelessness. Her work, and that of others (e.g., O'Loughlin, 2013c) suggests that recuperation of narrative ought to be a vital component of any vitalizing or politically aware pedagogy. Readers will also recognize in this argument an affinity with Freire's (1969) notion of generative themes. Freire's Education for critical consciousness (1969) was probably the original manifesto on critical action research, grounded in a critical reading of life history and current circumstance.

The type of pedagogy I propose is a depth pedagogy in that it takes account of inquiry into unconscious processes, and it is a local pedagogy, in that a generative and critical reading of curriculum must be necessarily grounded in the discursive contexts and immediate lives of children, and in the social situatedness of children's subjectivities in ancestral, cultural, ideological and historical lineages. This should assuredly be read as an argument against prescriptive, generic or standardized curriculum. It should not be read, however, as an argument for parochialism or insular pedagogy. Rather, it is a plea for a grounding of curriculum not only in personal narrative, but in narrative imaginaries such as the humanities (Tilleczek, 2014) and in critical aesthetics (MacDonald, 2014) that create expansive opportunities for identification with subaltern, sideways, and rhizomatic possibilities for growth.

At its most basic level, then, my argument is that if children are to come to question the implicit narratives of their own lived experience as well as questioning the grand-narratives of science, history, progress, sexuality, race relations, consumption, knowledge construction and so on, then they need to be engaged in a curriculum of inquiry by teachers who have already learned to question (Freire \& Faundez, 1989). This requires in part what I have termed elsewhere an evocative pedagogy (O'Loughlin, 2009) in which teachers develop the skills to work with children to uncover latent historical subjectivities, to explore the epistemologies underlying everyday discursive practices and ways of knowing (Lipman, 2010), and to engage children with alternative and subaltern identifications to create an expansive pedagogy in 
which each child can seek to find a place in the world and to imagine their lives otherwise. I have discussed elsewhere a dynamic concept of curriculum that would accompany such a pedagogical approach as regenerative curriculum (O’Loughlin, 2009).

The metaphor of teacher as analyst refers, therefore, to the evolving selfawareness of teachers about their own autobiographical and sociocultural origins, and about those characteristics of their experience that have fostered or inhibited their critical imaginations and their capacities to question prevailing epistemologies and discursive practices. It also refers to the level of attunement teachers exhibit towards children, and their sensitivity to what is necessary to engage children in learning to question. Do teachers exhibit receptivity toward children's emotions and do they understand the relationship between a child's emotional stance and that child's capacity for curiosity (Ginott, 2009)? Further, parallel to the teacher's own experience, is there a recognition that a child's latent subjectivity entails exploring ancestral, cultural and historical experiences as a way to empower children to understand their culturally and ancestrally constituted ways of knowing and to allow them, through interaction with literature, film, performance, discussion etc. to embrace alternative and subaltern identifications and ways of knowing, as well as to come to see their own ancestral lineages and epistemological inheritances as validated?

Having conceptualized pedagogy as collaborative, critical, narrative work, I imagine research as the documentation of that process by which people come to understand the active construction of their own subjectivities. Rather than offer an inert curriculum, in which all the answers are predetermined, and the student and teachers are reduced to active dispensers and receivers of knowledge respectively-what Freire characterized as banking education-I imagine teachers combining pedagogical and 'research' roles in a form of pedagogy in which the teacher's primary activity is that of annalist. The teacher, then, assists the children in documenting and chronicling the emergent curriculum and the kinds of questions and insights such curriculum generates. Speaking particularly of the possibilities of an indigenous pedagogy, I summarized the role of teacher as annalist this way:

Curriculum, in this conceptualization, is an organic process that gets constructed with children and with community stakeholders for the children of that particular community. Teachers might then consider themselves as documentarians of the collective unconscious of the 
community; documentarians of existing lore; and documentarians of the processes and products involved in constructing new forms of lore with children and community members. (O'Loughlin, 2009, p.162)

The question I am left with is whether we might not seed a movement of soulful, inquiring teachers who come together in powerful ways to equip themselves with analytic and epistemological capacities to engage in such adventurous pedagogy with children, documenting all the while the paths that are taken, and thereby creating a dynamic legacy for other teachers. Let's be honest with ourselves, however. This is a strategy that cannot work in the service of utilitarian modes of education that are focused only on value (cf. Appiah, 2015). It can only work for forms of schooling that seek to foster values of receptivity, cultural respect, open-mindedness, and critical imaginaries. In these coldly utilitarian times we need to provide leadership to progressively minded teachers to allow them to develop, document, and disseminate such practices.

\section{References}

American Psychiatric Association. (2013). Diagnostic and statistical manual of mental disorders. [Fifth edition: DSM-5]. Arlington: American Psychiatric Publishing. Appiah, K.A. (2015, Sept. 8). What is the point of college? New York Times Magazine. Retrieved from http://www.nytimes.com/2015/09/13/magazine/what-is-the-point-of-college.html on Sept. 14, 2015.

Atkinson, J. (2001). Trauma trails: Recreating song lines: The transgenerational transmission of trauma in Indigenous Australia. North Melbourne: Spinifex press.

Basch, M. (1989). The teacher, the transference, and development. In K. Field, B. Cohler, \& G. Wool (Eds.), Learning and education: Psychoanalytic perspectives (pp. 771787). Madison: International Universities Press

Biesta, G. (2009). Good education in an age of measurement: On the need to reconnect with the question of purpose in education. Education, Assessment, Evaluation, and Accountability, 21(1), 33-46.

Bion, W. R. (1962/1984). Learning from experience. London: Karnac.

Bloch., M., Swadener, B., \& Cannella, G. (Eds.). (2012). Reconceptualizing early childhood care and education: Critical questions, new imaginaries and social activism. New York: Peter Lang Publishing.

Boler, M. (1999). Feeling power: Emotions and education. New York: Routledge.

Bollas, C. (1989). The shadow of the object: Psychoanalysis of the unthought known. New York: Columbia University Press.

Borg, C., Buttigieg, J., \& Mayo, P. (Eds.). (2002). Gramsci and education. Lanham: Rowman \& Littlefield.

Britzman (2003). Practice makes practice: A critical study of learning to teach. (Rev. ed.). Albany: SUNY Press. 
Britzman, D. (1995). Beyond innocent readings: Educational ethnography as a crisis of representation. In W. Pink, \& G. Noblit (Eds.), Continuity and contradiction: The futures of the sociology of education (pp. 133-157). New York: Hampton Press.

Brookfield, S. (2004). The power of critical theory: Liberating adult learning and teaching. San Francisco: Jossey-Bass.

Counts, G. (1932/1969). Dare the schools build a new social order? New York: Arno Press \& The New York Times.

Cozarelli, L., \& Silin, M. (1989). The effects of narcissistic transferences on the teaching-learning process. In K. Field, B. Cohler \& G. Wool (Eds.). Learning and education: Psychoanalytic perspectives (pp. 809 823). Madison: International Universities Press.

Daloz, L. (2012). Mentor: Guiding the journey of adult learners ( $2^{\text {nd }}$ ed.). San Francisco: Jossey-Bass.

Daloz, L. (1986). Effective teaching and mentoring: Realizing the transformational power of adult learning experiences. San Francisco: Jossey-Bass.

Dewey, J. (1938/1998). Experience and education. Indianapolis: Kappa Delta Pi.

Danielson, C. (2013). The framework for teaching evaluation instrument, 2013 Edition: The newest rubric enhancing the links to the common core state standards, with clarity of language for ease of use and scoring.

Ekstein, R. (1989). From the love of learning to the love of teaching. In K. Field, B. Cohler, \& G. Wool (Eds.), Learning and education: Psychoanalytic perspectives (pp. 91 97). Madison: International Universities Press.

Fassin, D., \& Rechtman, R. (2009). The Empire of trauma: An inquiry into the conditions of victimhood. Princeton: Princeton University Press.

Field, K., Cohler, B., \& Wool, G. (Eds.). (1989). Learning and education: Psychoanalytic perspectives. Madison: International Universities Press.

Fine, M. (1994). Working the hyphens: Reinventing self and other in qualitative research. In N.K. Denzin, \& Y.S. Lincoln (Eds.), Handbook of qualitative research (pp. 70 82). London: Sage Publications.

Freire, P. (1970). Pedagogy of the oppressed. New York: Continuum.

Freire, P. (1969). Education for critical consciousness. New York: Continuum.

Freire, P., \& Faundez, A. (1989). Learning to question: A Pedagogy of liberation. Geneva: World Council of Churches.

Ginott, H. (2009). Between parent and child: The best-selling classic that revolutionized parent-child communication. New York: Random House.

Giroux, H. (2011). On critical pedagogy: Critical pedagogy today. London: Bloomsbury Press.

Gramsci, A. (1971). Selections from the prison notebooks. New York: International Publishers.

Greene, M. (2001). Releasing the Imagination: Essays on education, the arts, and social change. San Francisco: Jossey-Bass.

Greene, M. (1978). Landscapes of learning. New York: Teachers College Press. Henriques, J., Hollway, W., Urwin, C., Venn, C., \& Walkerdine, V. (1984). Changing the subject: Psychology, social regulation and subjectivity. London: Methuen.

Ibrahim. A., \& Steinberg, S. R. (Eds.). (2014). The critical youth studies reader. New York: Peter Lang Publishing. 
Horton, M. (1990). The long haul: An autobiography. New York: Doubleday. Horton, M., \& Freire, P. (1990). We make the road by walking: Conversations on education and social change. Philadelphia: Temple University Press.

Jersild, A. (1955). When teachers face themselves. New York: Teachers College Press. Kincheloe, J. (2008). Critical pedagogy primer. New York: Peter Lang Publishing. Lipman, M. (2010). Philosophy in the classroom (2 $2^{\text {nd }}$ ed.). Philadelphia: Temple University Press.

Littner, N. (1989). Reflections of early childhood family experiences in the educational situation. In K. Field, B. Cohler, \& G. Wool (Eds.), Learning and education: Psychoanalytic perspectives (pp. 825-848). Madison: International Universities Press.

MacDonald, M.B. (2014). Cultural studies of youth culture aesthetics as critical aesthetic education. In A. Ibrahim, \& S.R. Steinberg (Eds.), The critical youth studies reader (pp. 434- 443). New York: Peter Lang Publishing.

Mayo, P. (Ed.). (2010). Gramsci and educational thought. New York: Wiley.

McLaren, P. (1989). Life in Schools: An Introduction to critical pedagogy in the foundations of education. Boston: Allyn \& Bacon.

O'Loughlin, M. (2015a). Troubling naturalized trauma, essentialized therapy, and the asphyxiation of dangerous memory. In M. O'Loughlin (Ed.), The ethics of remembering and the consequences of forgetting: Trauma, history and memory (pp. 55-72). Lanham: Rowman \& Littlefield.

O'Loughlin, M. (Ed.). (2015b). The Ethics of Remembering and the Consequences of Forgetting: Trauma, History and Memory. Lanham: Rowman \& Littlefield.

O'Loughlin, M. (Ed.). (2013a). Psychodynamic Perspectives on Working with Children, Families and Schools. Lanham: Jason Aronson.

O'Loughlin, M. (Ed.). (2013b). The Uses of Psychoanalysis in Working with Children's Emotional Lives. Lanham: Jason Aronson.

O'Loughlin, M. (2013c). Reclaiming genealogy, memory and history: The psychodynamic potential for reparative therapy in contemporary South Africa. In C. Smith, G. Lobban, \& M. O'Loughlin (Eds.), Psychodynamic psychotherapy in contemporary South Africa: Contexts, theories, practices (pp. 242-271). Johannesburg: Wits University Press.

O'Loughlin, M. (2012a). Countering the rush to medication: Psychodynamic, intergenerational, and cultural considerations in understanding children's distress. In U.S. Nayar (Ed.), International handbook on mental health of children and adolescents: Culture, policy \& practices (pp. 275-284). Delhi: Sage.

O'Loughlin, M. (2012b). Still waiting for the revolution. In M. Bloch., B. Swadener, \& G. Cannella, G. (Eds.), Reconceptualizing early childhood care and education: Critical questions, new imaginaries and social activism. New York: Peter Lang Publishing.

O'Loughlin, M. (2009). The subject of childhood. New York: Peter Lang.

O'Loughlin, M., \& Charles, M. (Eds.). (2015). Fragments of trauma and the social production of suffering: Trauma, History and Memory. Lanham: Rowman \& Littlefield. O'Loughlin, M., \& Charles, M. (2012). Psychiatric survivors, psychiatric treatments, and societal prejudice: An inquiry into the experience of an extremely marginal group. In G. Cannella, \& S. Steinberg (Eds.), Critical qualitative research reader (pp. 500-511). New York: Peter Lang Publishing.

O'Loughlin, M., Charles, M. Crosby, J. Arac, S., \& Queler, M. (2014). Field note: Clo- 
sing the gap: Narrating the prose of severe psychic suffering. Psychoanalysis Culture \& Society, 19(1), 98-106.

O’Loughlin, M., \& Van Zile, P. (2012). Becoming revolutionaries: Toward non-teleological and non-normative notions of youth growth, In A. Ibrahim, \& S. R. Steinberg, (Eds.), The critical youth studies reader (pp. 47 57). New York: Peter Lang Publishing. Paley, V. (2004). A child's work: The importance of fantasy play. Chicago: University of Chicago Press.

Pianta, R. (1999). Enhancing relationships between children and teachers. Washington DC: APA Books.

Stepansky, P.E. (2009). Psychoanalysis at the margins. New York: Other Press Professional.

Stockton, K. B. (2009). The queer child: On growing sideways in the twentieth century. Durham: Duke University Press.

Tilleczek, K. (2014). Theorizing young lives: Biography, society, and time, In A. Ibrahim, \& S.R. Steinberg (Eds.), The critical youth studies reader (pp. 15-25). New York: Peter Lang Publishing.

Watters, E. (2010). Crazy like us: The globalization of the American psyche. New York: Free Press.

\section{Author:}

Michael O'Loughlin, Ph.D.

Adelphi University

School of Education and Ph.D. program in Clinical Psychology

1 South Ave

P.O. Box 701

New York

11530-0701

USA

Email: michaeloloughlinphd@gmail.com 